Vote, and the other salaries and expenses of the Government Laboratory were charged to the Customs and Excise Vote.

The Estimate for the Department of Agriculture and Technical Instruction, Ireland, exhibits a net increase of $10,253 \mathrm{l}$. Of this amount, $3275 \mathrm{l}$. is due to an increased grant-in-aid to the Royal College of Science, and $5500 \mathrm{l}$. to an increase in the annual grants to schools and classes of science and art and technical instruction. The sums of I7,oool. granted from the Development Fund for the purchase of areas of afforestation, \&c., and 10,0ool. for the improvement of horse breeding, are appropriated in aid of the Vote for this Department to cover the expenses incurred for those purposes.

The total provision for education, science, and art is $19,141,264 l$., being a net increase of $468,900 l$. on the amount voted in 1910. The Estimate for the Board of Education shows a net increase of $3 \mathrm{ro}, 84 \mathrm{ol}$., of which 229,355 . arises under grants in respect of public elementary schools, 13,00ol. under grants for training of teachers, and $64,500 l$. under grants for technical institutions, schools of art, evening schools, \&c.

The Estimate for Universities and Colleges, Great Britain, and Intermediate Education, Wales, exceeds that for 1910-11 by $64,700 l$, , after taking into account a Sup plementary Grant of $21,000 l$. in I9 10. Of this increase, $10,500 l$. occurs under the subhead for Scottish Universities, and $50,000 l$. under Colleges, Great Britain.

The Estimate for Public Education, Scotland, shows an increase of $82,86 \mathrm{gl}$. The estimated number of scholars in day schools has risen from 737,576 to 764,397 for the year, and the annual grants for day scholars are increased by 64,647 . The provision for grants for continuation classes and secondary schools shows an increase of $16,800 l$.

The increase of $18,176 l$. in the Estimates for Universities and Colleges, Ireland, is due to additional grants for land, buildings, and equipment for the Irish universities.

Among the amounts required for different purposes, the following are interesting:- art and science buildings, Great Britain, 99,90ol.; surveys of the United Kingdom, 187,344l.; Government chemist, 19,088l.; Board of Educa tion, $14,375,442 l$.; scientific investigation, $61,603 l$.; universities and colleges, Great Britain, and intermediate education, Wales, 303,80ol.; public education in Scotland, 2,336,594l.; public education in Ireland, I, 653,324l.; and universities and colleges, Ireland, $186,256 l$.

A table included in the paper provides interesting information as to the growth of expenditure or otherwise under different headings. Take, for instance, the cases of the Board of Education, and the universities and colleges in Great Britain and intermediate education in Wales, the grants have steadily increased since 1902-3. Under the heading scientific investigations there is no such decided increase to record, as the following table shows:-

\begin{tabular}{cccc|cccc}
$1902-3$ & $\ldots$ & $\ldots$ & 62,932 & $1906-7$ & $\ldots$ & $\ldots$ & $56,8<8$ \\
$1903-4$ & $\ldots$ & $\ldots$ & 87.300 & $1907-8$ & $\ldots$ & $\ldots$ & 53,823 \\
$1904-5$ & $\ldots$ & $\ldots$ & 54,484 & $1908-9$ & $\ldots$ & $\ldots$ & 55,349 \\
$1905-6$ & $\ldots$ & $\ldots$ & 53,343 & $1909-10$ & $\ldots$ & $\ldots$ & 83,338 \\
Grants in Session 1910 for 1910-1 I, $£ 74,228$ \\
Estimates I9I I-I91 2, $£ 61,603$.
\end{tabular}

THE IMPERIAL EDUCATION CONFERENCE.

THE following representatives from the self-governing dominions are expected at the forthcoming Imperial Education Conference, which will be held on April 25-28 inclusive :-The Dominion of Canada: The Hon. R. A. Pyne, Minister of Education, Ontario, or Dr. A. H. W. Colquhoun, Deputy Minister of Education, Ontario; Dr. A. H. McKay, Superintendent of Education, Nova Scotia, with whom will be associated the Rev. Dr. MacGill, professor of philosophy, University of Dalhousie; the Hon. George R. Coldwell, Minister of Education, Manitoba; the Hon. Henry E. Young, Minister of Education, British Columbia; the Hon. W. F. A. Turgeon, Attorney-General, Saskatchewan. The Commonwealth of Australia: Mr. P. Board, Under Secretary in the Department of Public Instruction and Director of Education, New South Wales; Mr. C. R. P. Andrews, Inspector-General of Schools, Western Australia. The Union of South Africa: Dr. NO. 2 I62, VOL. 86]
Thomas Muir, C.M.G., F.R.S., Superintendent-General, Cape of Grood Hope; Dr. W. J. Viljoen, Director of Education, Orange Free State.

The Dominion of New Zealand will be represented by the Hon. Sir William Hall-Jones, K.C.M.G., High Commissioner in London for the Dominion, and the States of South Australia and Tasmania will be represented, respectively, by the Hon. A. A. Kirkpatrick, Agent-General in London for the State of South Australia, and the Hon. John McCall, Agent-General in London for the State of Tasmania.

The following local Governments in India have arranged to be represented as follows:- the Government of Madras by Dr. A. G. Bourne, F.R.S., Director of Public Instruction in the Presidency of Madras; the Government of Bombay by Mr. A. L. Covernton, principal and professor of English literature, Elphinstone College, Bombay; the Government of Bengal by Mr. B. Heaton, principal of the Sibpur Civil Engineering College, Bengal; the Government of the Central Provinces by Mr. S. C. Hill, late Director of Public Instruction in the Central Provinces, and $\mathrm{Mr}$. C. E. W. Jones, principal of the Morris College, Nagpur; the Government of Burma by Mr. W: G. Wedderspoon, Inspector of Normal Schools, Burma.

The representation of the Crown Colonies will be as follows :-Falkland Islands, Mr. T. A. V. Best, Colonial Secretary; Gold Coast Colony, Mr. J. W. Church, Director of Education; Jamaica, Mr. G. H. Deerr, Inspector of Schools; Leeward Islands, Mr. H. E. W. Grant, Colonial Secretary; Malta, the Hon. Prof. Enrico Magro, Director of. Public Instruction and Rector of the University of Malta; Straits Settlements, Mr. H. T. Clark, principal of the Malay College, Malacca: Trinidad, Mr. George Goodwille, formerly a Member of the Legislative Council.

The conference will be attended by representatives of the India and Colonial Offices and of all the Home Education Departments-English, Scotch, and Irish. The States of. Guernsey, Jersey, and the Isle of Man have been asked to nominate representatives.

The morning sessions of the conference will be confined to official representatives, and devoted to the consideration by them of such matters as the various overseas Governments have suggested for discussion or any delegate may wish to bring before the conference. The arrangements for the afternoon sessions will be announced later. A preliminary meeting of official representatives will be held on Monday, April 24, for the purpose of settling finally the programme for the morning sessions of the conference.

\section{AGRICULTURAL BULLETINS.}

THE Agricultural Experiment Station of the University of Wisconsin is one of the most active centres of scientific work in agricuiture in the United States. Problems are attacked from two distinct points of view: the economic, in which the object is to show how crops may be produced a little more cheaply than at present, and the scientific, the problem being investigated for the sake of the general principles it may bring out. Two sets of bulletins are therefore issued, the popular bulletin, intended for farmers, dealing mainly with local problems, and always from the local point of view, and the research bulletins. The popular bulletins are fully equal to any others in the United States, and much ahead of anything we publish here for farmers; in the series before us the subjects dealt with include land drainage, curing of seed corn, control of various weeds, draft-horse judging, a discussion of the methods of paying for milk at cheese factories, and so on. The research bulletins are the scientific papers of the staff; as usual in the United States, each paper is published separately, and there is no common journal in which they all appear.

Three of the papers referred to above deal with cheesemaking, perhaps the least understood of all agricultural processes. Messrs. Sammis, Suzuki, and Laabs discuss the factors regulating the rate at which whey separates from curd in the cheese vat. High acidity, high temperature, and pressure applied to the curd all facilitate rapid separation, but, on the other hand, variations in the proportions of rennet and the time of action of the rennet have no effect. In another paper Messrs. Suzuki, Hastings, and 